\title{
EFFECTS OF ANTI-UV FILM AND PROTECTIVE ATMOSPHERE ON FRESH-CUT ICEBERG LETTUCE PRESERVATION
}

\author{
F. Galgano ${ }^{a *}$, M.C. Caruso ${ }^{a}$, N.M. Ventura ${ }^{\text {b }}$, C. Magno ${ }^{c}$ and F. Favati ${ }^{d}$

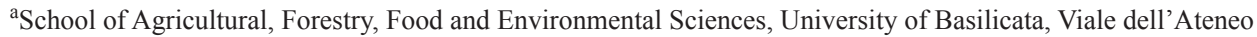 \\ Lucano 10, 85100 Potenza. Italy \\ ${ }^{\mathrm{b}}$ Ortomad Soc. Agr. srl, Via Lago Carezza, 84098 Pontecagnano (Sa). Italy \\ ${ }^{c}$ VIBAC SpA, Strada Ticineto - Salita S. Salvatore, 15040 Ticineto (AL). Italy \\ ${ }^{\mathrm{d}}$ Department of Biotechnology, University of Verona, Strada Le Grazie 15, 37134 Verona. Italy
}

(Received: 2 May 2016; accepted: 13 August 2016)

\begin{abstract}
The aim of this research was to study the shelf-life of fresh-cut iceberg lettuce, testing a packaging film manufactured with and without addition of anti-UV compounds, and using two different protective atmospheres $\left(\mathrm{N}_{2} / \mathrm{CO}_{2} 70 / 30 \%\right.$ and $\mathrm{Ar} / \mathrm{CO}_{2} 80 / 20 \%$ ). In order to simulate the most common retail storage conditions, the samples were stored at $6{ }^{\circ} \mathrm{C}$ under artificial light by using real supermarket refrigerated exposition stands. The data obtained showed that the use of an anti-UV film always causes a lower quality decay of the product; in any case, the best results were obtained when the anti-UV film was utilized in association with the packaging atmosphere consisting of $\mathrm{Ar}_{\text {and }} \mathrm{CO}_{2}$ $(80 / 20 \%)$ gas mixture.
\end{abstract}

Keywords: anti-UV film, food packaging, fresh-cut vegetables, lettuce, light exposure, protective atmosphere

Fresh-cut products can be defined as fresh fruit or vegetables that after trimming and/or peeling are cut, washed, dried, packaged in pouches or boxes, and stored at chilling conditions. However, processing may accelerate various degradation processes resulting in a shelf-life no longer than 5-7 days. This is due to the dramatic increase of processes such as respiration, transpiration, and enzymatic activities as a consequence of the post-harvest treatments, as well as to the proliferation of spoilage microorganisms (Rico et al., 2007). Deterioration of the products can be retarded by using suitable pre-treatments and/or adequate packaging systems; however, the storage temperature represents the most important parameter allowing to keep spoiling of the product under control throughout the processing, transportation, distribution, and storage steps (GALGANO et al., 2015).

Among the several factors affecting the shelf-life length, exposition to natural or artificial light, especially in the UV-B region, should also be taken into account, because light may cause degradation of light-sensitive moieties, such as carotenoids and vitamins, having high nutritional value, as well as loss of colour, reduction of the aroma, and development of off-flavours. Despite these problems, the actual marketing strategies for fresh-cut products require to present these food items under strong light conditions, therefore the package films may play an important role in reducing the possible side effects of overexposure to light. For this purpose, packaging materials with addition of anti-UV compounds have been formulated in order to limit nutritional and sensorial damages to fruit and vegetables. However, few studies have investigated the effect of light on the quality parameters of vegetables (SANZ et

\footnotetext{
* To whom correspondence should be addressed.

Phone: +39 0971 205570; fax: +390971 205503; e-mail: fernanda.galgano@unibas.it
}

0139-3006/\$20.00 @ 2017 Akadémiai Kiadó, Budapest 
al., 2007, 2009; Ayala et al., 2009; Olarte et al., 2009). On the other hand, protective atmosphere packaging (PAP) is effective in prolonging the shelf-life of fresh-cut products, by decreasing the $\mathrm{O}_{2}$ and increasing the $\mathrm{CO}_{2}$ concentration in the headspace of the package, with a consequent decrease of the respiration rate and lower weight losses. Recently, there has been a great interest in the potential benefits of noble gases in PAP applications, such as argon (Ar). It has been demonstrated that Ar can offer performances that are better than those of nitrogen, due to its physical characteristics. In particular, the higher density of argon (1650 $\left.\mathrm{kg} \mathrm{m}^{-3}\right)$ than nitrogen $\left(1153 \mathrm{~kg} \mathrm{~m}^{-3}\right)$ allows a more effective removal of oxygen, with a lower level of residual oxygen in the package headspace (SPENCER \& HuMPHREYs, 2003). Moreover, $\mathrm{Ar}$ is more soluble in water and in fats than nitrogen; this fact facilitates the removal of the oxygen dissolved and incorporated in food matrices, when $\mathrm{Ar}$ is utilized. From a technical point of view, this advantage can be exploited to apply faster vacuum cycles, lower pressures of gases entering the package, and the use of lower gas volume to remove the present oxygen, with considerable time-savings and lower loss of volatile compounds of the packaged food (Spencer \& Humphreys, 2003). Furthermore, Ar is also very effective in inhibiting the respiratory enzymes and controlling enzymatic browning (O'BEIRNE et al., 2011); this fact can be of particular interest for fresh-cut vegetables. In particular, it has been reported that $\mathrm{Ar}$ in PAP of fresh-cut fruit and vegetables reduces microbial spoilage and improves product quality retention (JAmie \& SAltveit, 2002). However, few data are available in the literature dealing with the influence of Ar on the shelf-life of fresh-cut vegetables, in particular of lettuce (JAmie \& SAltveit, 2002; Rocculi et al., 2004, 2005; Zhang et al., 2008).

The aim of this research was to study the shelf-life of fresh-cut iceberg lettuce, stored under artificial light at $6{ }^{\circ} \mathrm{C}$ using real supermarket refrigerated exposition stands, testing two different packaging films, manufactured with and without anti-UV compounds, and using two different gas mixtures, one of them including Ar as principal gas.

\section{Materials and methods}

\subsection{Sampling}

Iceberg lettuce (Lactuca sativa L.) was provided by Società Agricola Ortomad srl (Pontecagnano, SA, Italy), and immediately after harvesting the vegetables were quickly cooled to $6^{\circ} \mathrm{C}$ for storage.

\subsection{Sample processing}

Samples suitable for processing were cut in pieces of about $5 \mathrm{~cm}$, washed with chlorine solution (100 ppm), centrifuged to remove any excess of water and packed to obtain 48 bags containing $260 \mathrm{~g}$ of lettuce. The investigated lettuces were packaged under two different protective atmospheres $\left(\mathrm{N}_{2} / \mathrm{CO}_{2} 70 / 30 \%\right.$ and $\mathrm{Ar} / \mathrm{CO}_{2} 80 / 20 \%$ ) by using a BOPP (BI-oriented polypropylene) anti-fog coextruded film [30 $\mu \mathrm{m}$ thickness; oxygen permeability value of $1800 \mathrm{~cm}^{3} \mathrm{~m}^{-2} \mathrm{~d}^{-1} \mathrm{~atm}^{-1}$ measured at $23{ }^{\circ} \mathrm{C}$ and $0 \% \mathrm{R} . \mathrm{H}$; water vapour transmission rate value (WVTR) of $6.5 \mathrm{~g} \mathrm{~m}^{-2} \mathrm{~d}^{-1}$ measured at $37.8{ }^{\circ} \mathrm{C}$ and $100 \%$ R.H.] manufactured with (film code XCTGV) and without (film code CTG) addition of anti-UV compounds (UV barrier 70\%) and provided by VIBAC SpA (Ticineto, AL, Italy), for a total of 4 treatments. Replacement of air in PAP operation has been realized by gas flushing system with an equipment provided by Ishida company (Japan). 
In order to simulate the most common retail storage conditions, the samples were stored at $6{ }^{\circ} \mathrm{C}$ under artificial light (L/36W/76/Natura Osram, Milano, Italy) by using real supermarket refrigerated exposition stands. The tests lasted up to 9 days and the lettuces were sampled at $0,3,7$, and 9 days for analyses. At the beginning and at the end of storage the content of $\mathrm{O}_{2}$ and $\mathrm{CO}_{2}$ was measured using a Dansensor CheckPoint II headspace analyzer (Dansensor, Segrate, MI, Italy).

\subsection{Chemical analyses}

Ten grams of sample were chopped and homogenized, then placed in a $100 \mathrm{ml}$ volumetric flask and brought up to volume with deionised water. After $10 \mathrm{~min}$, the sample was filtered. The $\mathrm{pH}$ was measured on the extract by using a $\mathrm{pH}$ meter (Model SA720, Orion, Milano, Italy). Titratable acidity (TA) was determined by titration with $\mathrm{NaOH} 0.1 \mathrm{~mol}^{-1}$ until $\mathrm{pH} 8.1$, and expressed as grams of anhydrous citric acid per $100 \mathrm{~g}$ of sample (AOAC, 1990). Total soluble solids (TSS) contents were assessed at $20{ }^{\circ} \mathrm{C}$ by using an Abbe refractomer (Carl Zeiss, Jena, Germany) and expressed as ${ }^{\circ}$ Brix (AOAC, 1990). Browning intensity was determined spectrophotometrically at $340 \mathrm{~nm}$, as proposed by COUTURE and co-workers (1993). Colour was measured on the lettuce surface, considering the green part of the leaf, using a Minolta Chroma meter CR-300 with a D 65 illuminant, using CIELAB L*, a*, b* values (4 replicates for each index, for a total of 12 analytical data). The chlorophyll content was determined spectrophotometrically at 647 and $670 \mathrm{~nm}$, as detailed by INSKEEP and BLOOM (1985). Weight loss was estimated gravimetrically, weighing all samples after each storage period, and expressed as percentage of the initial sample weight. Vitamin $\mathrm{C}$ content was assessed by HPLC according to the method proposed by GALGANO and co-workers (2002) and reported as $\mathrm{mg}$ vitamin $\mathrm{C} / \mathrm{kg}$ fresh product.

\subsection{Microbiological analyses}

For microbiological analyses $10 \mathrm{~g}$ of leaf samples was added to $90 \mathrm{ml}$ of sterile $0.85 \%$ sodium chloride solution and homogenized for $120 \mathrm{sec}$ using a Stomacher 400 blender (International PBI, Milano, Italy). Filter stomacher bags were used to separate particles of lettuce fibre from the homogenates, and tenfold dilutions series were made in peptone buffered water as required for plating. The following microbial groups were evaluated: total viable aerobic mesophilic on Plate Count Agar (Oxoid, Basingstoke, England) at $30{ }^{\circ} \mathrm{C}$ for $48 \mathrm{~h}$; total coliforms on Chromogenic E. coli/Coliform Medium (Oxoid) inoculated by double layer inclusion at $37{ }^{\circ} \mathrm{C}$ for $48 \mathrm{~h}$; Pseudomonas spp. on Pseudomonas Agar base with CFC supplement (Oxoid) at $30{ }^{\circ} \mathrm{C}$ for $48 \mathrm{~h}$; moulds and yeasts on Glucose Yeast Extract Agar (Oxoid) with a $10 \mathrm{mg} \mathrm{ml}^{-1}$ oxytetracycline-chlorhydrate solution, inoculated by inclusion and incubated at $25^{\circ} \mathrm{C}$ for 5 days. The experimental design was based on four replicates for each treatment.

\subsection{Statistical analysis}

In order to study the effect of packaging system on iceberg lettuce quality characteristics, data were processed by one-way analysis of variance (one-way ANOVA) and the Least Significant Difference (LSD) test was performed for comparison of means $(\mathrm{P}<0.05)$. All statistical procedures were computed using the statistical package SYSTAT for Windows (ver. 10, 2003) (Systat Software, Chicago, USA). 


\section{Results and discussion}

Data of some physico-chemical characteristics of fresh-cut lettuce packed with different methods are shown in Table 1. Weight loss reached a maximum value of about $1.1 \%$ at the end of storage, but no significant differences were detected among the different treatments (data not shown). Total soluble solids remained substantially constant over the whole storage period, with a mean value of $1.34^{\circ}$ Brix for all samples, being not influenced by either the packaging film or the atmosphere utilized (data not shown). The concentration of $\mathrm{O}_{2}$ in the samples packaged before storage was on average $5 \%$ and decreased to $2.6 \%$ after 9 days of storage. The content of $\mathrm{CO}_{2}$ remained stable over time and corresponding to the initial concentration in the two different protective atmospheres utilized $\left(30 \%\right.$ in $\mathrm{N}_{2} / \mathrm{CO}_{2}$ and $20 \%$ in $\left.\mathrm{Ar} / \mathrm{CO}_{2}\right)$.

Table 1. Principal physico-chemical characteristics of fresh-cut iceberg lettuce stored at $6{ }^{\circ} \mathrm{C}$ in different packaging systems

\begin{tabular}{|c|c|c|c|c|c|}
\hline $\begin{array}{l}\text { Physico-chemical } \\
\text { parameters }\end{array}$ & $\begin{array}{l}\text { Time } \\
\text { (days) }\end{array}$ & $\begin{array}{l}\mathrm{XCTGV} \\
\mathrm{Ar} / \mathrm{CO}_{2} \\
\end{array}$ & $\begin{array}{l}\mathrm{XCTGV} \\
\mathrm{N}_{2} / \mathrm{CO}_{2} \\
\end{array}$ & $\begin{array}{c}\mathrm{CTG} \\
\mathrm{Ar} / \mathrm{CO}_{2} \\
\end{array}$ & $\begin{array}{c}\mathrm{CTG} \\
\mathrm{N}_{2} / \mathrm{CO}_{2} \\
\end{array}$ \\
\hline \multirow{4}{*}{$\mathrm{pH}$} & 0 & $6.60 \mathrm{a}$ & $6.58 \mathrm{a}$ & $6.61 \mathrm{a}$ & $6.66 a$ \\
\hline & 3 & $6.59 \mathrm{a}$ & $6.55 \mathrm{a}$ & $6.56 a$ & $6.54 \mathrm{a}$ \\
\hline & 7 & $6.26 \mathrm{~b}$ & $5.72 b$ & $5.66 \mathrm{~b}$ & $5.71 \mathrm{~b}$ \\
\hline & 9 & $6.45 \mathrm{a}$ & $6.35 \mathrm{c}$ & $6.43 a$ & $6.44 a$ \\
\hline \multirow{3}{*}{$\begin{array}{l}\text { Titratable } \\
\text { acidity }(\%)\end{array}$} & 0 & $0.05 \mathrm{a}$ & $0.06 \mathrm{a}$ & $0.07 \mathrm{a}$ & $0.07 \mathrm{a}$ \\
\hline & 3 & $0.08 \mathrm{a}$ & $0.08 \mathrm{a}$ & $0.08 \mathrm{a}$ & $0.08 \mathrm{a}$ \\
\hline & 7 & $0.19 b$ & $0.24 b$ & $0.27 b$ & $0.25 b$ \\
\hline \multirow{4}{*}{$\mathrm{L}^{*}$} & 9 & $0.12 \mathrm{c}$ & $0.22 b$ & $0.17 \mathrm{c}$ & $0.19 \mathrm{c}$ \\
\hline & 0 & $86.74 a$ & $83.24 \mathrm{a}$ & $87.78 \mathrm{a}$ & $82.05 \mathrm{a}$ \\
\hline & 3 & $84.38 \mathrm{a}$ & $80.50 \mathrm{~b}$ & $81.89 b$ & $80.68 \mathrm{a}$ \\
\hline & 7 & $80.12 b$ & $80.33 b$ & $83.39 \mathrm{~b}$ & $76.18 b$ \\
\hline \multirow{4}{*}{$a^{*}$} & 9 & $81.15 b$ & $78.13 b$ & $73.37 \mathrm{c}$ & $74.28 b$ \\
\hline & 0 & $-16.42 \mathrm{a}$ & $-15.21 \mathrm{a}$ & $-18.50 \mathrm{a}$ & $-16.33 a$ \\
\hline & 3 & $-15.92 \mathrm{a}$ & $-14.74 \mathrm{a}$ & $-17.45 a$ & $-14.56 \mathrm{a}$ \\
\hline & 7 & $-13.88 \mathrm{a}$ & $-14.16 \mathrm{a}$ & $-14.34 b$ & $-12.72 b$ \\
\hline \multirow{4}{*}{$b^{*}$} & 9 & $-14.03 \mathrm{a}$ & $-13.48 \mathrm{a}$ & $-14.26 b$ & $-11.89 b$ \\
\hline & 0 & $26.77 \mathrm{a}$ & $24.59 \mathrm{a}$ & $28.31 \mathrm{a}$ & $26.06 \mathrm{a}$ \\
\hline & 3 & $28.18 \mathrm{a}$ & $25.86 \mathrm{a}$ & $29.33 a$ & $28.80 \mathrm{a}$ \\
\hline & 7 & $28.01 \mathrm{a}$ & $27.01 \mathrm{a}$ & $30.77 \mathrm{a}$ & $33.46 \mathrm{~b}$ \\
\hline \multirow{5}{*}{$\begin{array}{l}\text { Chlorophyll } \\
\left(\mathrm{mg} \mathrm{g}^{-1}\right)\end{array}$} & 9 & $28.04 \mathrm{a}$ & $31.16 \mathrm{~b}$ & $38.78 b$ & $39.44 \mathrm{c}$ \\
\hline & 0 & $0.69 a$ & $0.54 \mathrm{a}$ & $0.62 \mathrm{a}$ & $0.63 a$ \\
\hline & 3 & $0.63 a$ & $0.43 b$ & $0.54 \mathrm{a}$ & $0.42 \mathrm{~b}$ \\
\hline & 7 & $0.48 b$ & $0.41 b$ & $0.40 \mathrm{a}$ & $0.35 b c$ \\
\hline & 9 & $0.50 \mathrm{~b}$ & $0.36 \mathrm{~b}$ & $0.33 b$ & $0.27 \mathrm{~cd}$ \\
\hline
\end{tabular}

XCTGV: film with anti-UV compounds; CTG: film without anti-UV compounds.

Means within the same column with different letters are significantly different (LSD test at $\mathrm{P}<0.05$ ). 
After 7 days of storage, titratable acidity and $\mathrm{pH}$ showed statistically significant variations in all samples, and at the end of the trial the lettuces packed with XCTGV film under $\mathrm{N}_{2} / \mathrm{CO}_{2}$ showed the highest and the lowest values for titratable acidity and $\mathrm{pH}$, respectively, in comparison to those recorded in all the other samples. However, these chemical parameters did not contribute to differentiating lettuces on the basis of the packaging system.

Browning of fresh fruit and vegetables is generally considered the most important factor limiting the shelf-life and marketability of fresh-cut lettuce (ROJAS-GrAÜ et al., 2009), colour appearance being the main perception for consumer acceptability. In green vegetables, such as lettuce, the senescence process usually leads to yellow tissue coloration, due to chlorophyll degradation and the formation of pheophytins (ROJAS-GraÜ et al., 2009). This phenomenon can be prevented, or at least slowed down, by limiting vegetables exposure to light and choosing an appropriate packaging atmosphere. In this study, the best combination for delaying chlorophyll degradation and reducing browning intensity of iceberg lettuce was the use of XCTGV film with anti-UV compounds combined with atmospheres enriched in $\mathrm{Ar}$ (Fig. 1, Table 1). The highest chlorophyll degradation (57\%) and browning intensity increase $(>80 \%)$ were observed in lettuces packaged under $\mathrm{N}_{2} / \mathrm{CO}_{2}$ and using the CTG film with no anti-UV compounds. These results could be attributed to the higher solubility of Ar in water, hence in the aqueous layer of the cut vegetable tissues, in comparison with $\mathrm{N}_{2}$; furthermore, Ar may chemically interfere with the activity of enzymes such as polyphenol oxidase and/or lessen $\mathrm{O}_{2}$ concentration, the latter being fundamental for the oxidative processes (Rocculi et al., 2005). Moreover, a significant and negative correlation between browning intensity and chlorophyll content was recorded (Pearson coefficient $\mathrm{r}=-0.66$ at $\mathrm{P}<0.05$ ).

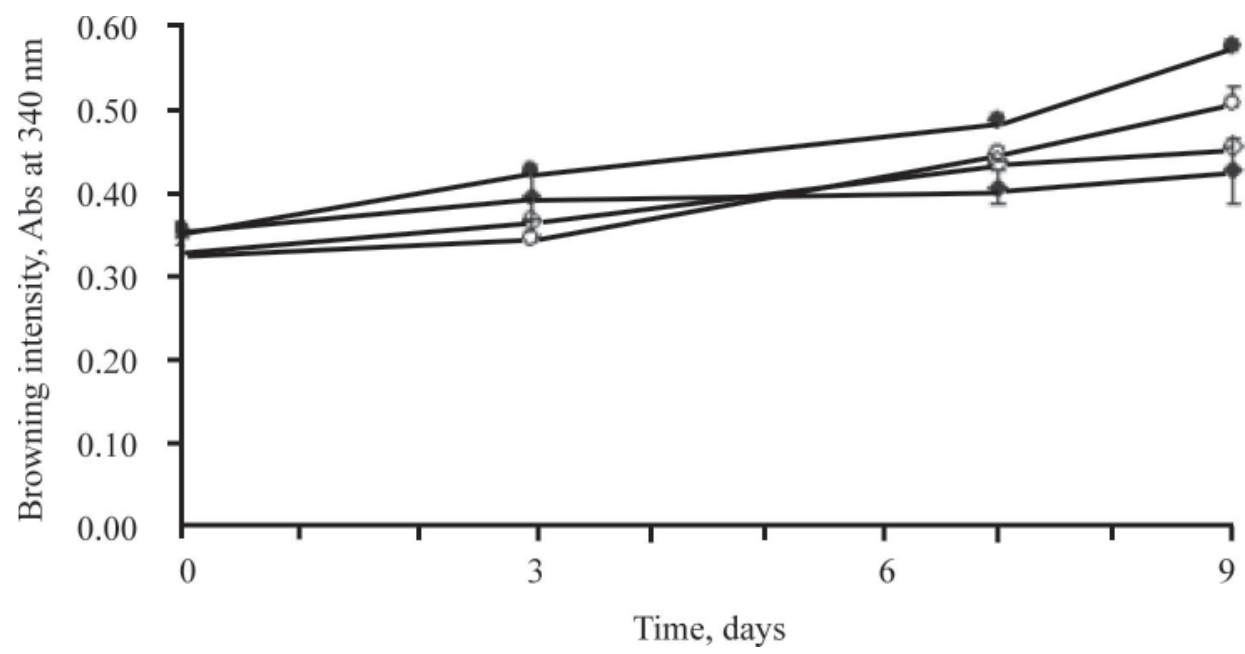

Fig. 1. Browning intensity in fresh-cut iceberg lettuce stored at $6{ }^{\circ} \mathrm{C}$ as a function of time and packaging treatment $\diamond:$ XCTGV Ar/CO $;$ O: XCTGV N $/ 2 \mathrm{CO}_{2} ; \diamond: \mathrm{CTG} \mathrm{Ar} / \mathrm{CO}_{2} ; \bigcirc: \mathrm{CTG} \mathrm{N}_{2} / \mathrm{CO}_{2}$

In the studied lettuce samples, also the colour coordinates showed significant variations over time, depending on the packaging system used. In particular, lightness ( $\left.\mathrm{L}^{*}\right)$ decreased over the whole storage period in all samples, and this reduction was more marked for lettuces 
packed using the CTG film, either under $\mathrm{N}_{2} / \mathrm{CO}_{2}$ or $\mathrm{AR} / \mathrm{CO}_{2}$, in which lightness intensity reached the minimum values. Conversely, during storage $\mathrm{a}^{*}$ and $\mathrm{b}^{*}$ generally increased, indicating a decrease in greenness ( $a^{*}$ value) and an increase in yellowness ( $b^{*}$ value). However, while the most significant time-dependent increase was observed for lettuces packed under $\mathrm{N}_{2} / \mathrm{CO}_{2}$ with the CTG film, $\mathrm{a}^{*}$ and $\mathrm{b}^{*}$ did not significantly change over the whole storage period for lettuces packed under $\mathrm{Ar} / \mathrm{CO}_{2}$ with the XCTGV film; a significant increase was recorded after 9 days only for the $b^{*}$ value of the samples packed under $\mathrm{N}_{2} / \mathrm{CO}_{2}$ with the XCTGV film.

There is scarce information about the effect of PAP on nutrient composition of fresh-cut fruit and vegetables, such as vitamin C (RoJAs-Graü et al., 2009; MartínEZ-SÁnChEz, et al., 2011). High $\mathrm{O}_{2}$ concentrations principally affect vitamin $\mathrm{C}$ degradation; however, it has been reported that also high $\mathrm{CO}_{2}$ levels can contribute to vitamin $\mathrm{C}$ loss, stimulating ascorbic acid oxidation, inhibiting the reduction of DHA to ascorbic acid and/or accelerating ascorbate peroxidase-catalysed oxidation processes (RoJAs-Graü et al., 2009). Moreover, also light exposure had effect on vitamin $\mathrm{C}$ retention; in fact, in our study the main loss $(>70 \%)$ was obtained in lettuces packed in CTG film under gas mixture with the highest concentration of $\mathrm{CO}_{2}\left(\mathrm{~N}_{2} / \mathrm{CO}_{2} 70 / 30\right)$ (Fig. 2), while the lowest loss (about 30\%) was obtained using XCTGV film with gas mixture $\mathrm{Ar} / \mathrm{CO}_{2}(80 / 20)$. Similar trends were observed for lettuces packed either with XCTGV film under $\mathrm{N}_{2} / \mathrm{CO}_{2}$ or CTG film under $\mathrm{Ar} / \mathrm{CO}_{2}$. Conversely, MarTínez-SÁnchez and co-workers (2011) have reported that light exposure does not affect the vitamin $\mathrm{C}$ content of Romaine lettuce.

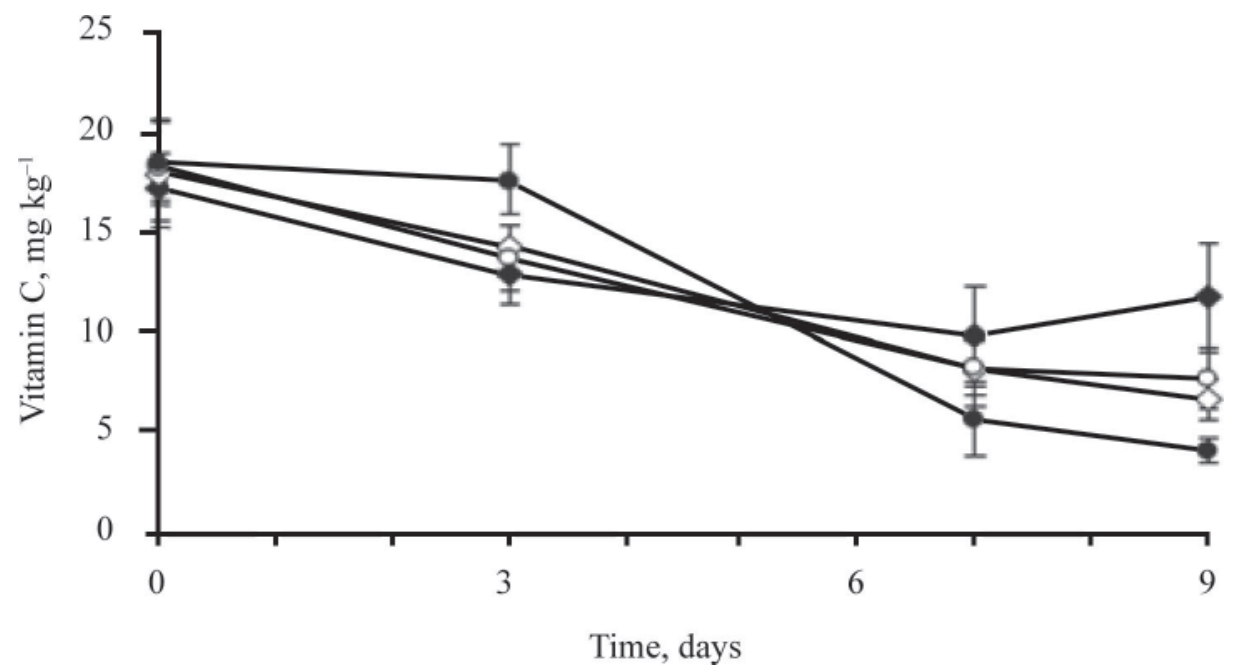

Fig. 2. Vitamin $\mathrm{C}$ content in fresh-cut iceberg lettuce stored at $6{ }^{\circ} \mathrm{C}$ as a function of time and packaging treatment $\diamond:$ XCTGV Ar/CO $;$ O: XCTGV N $/ 2 \mathrm{CO}_{2} ; \diamond: \mathrm{CTG} \mathrm{Ar} / \mathrm{CO}_{2} ; \bigcirc: \mathrm{CTG} \mathrm{N}_{2} / \mathrm{CO}_{2}$

The iceberg lettuce at time 0 had a good microbiological quality; in particular, mould, yeast, and Pseudomonas count were not detectable $\left(<1 \log \mathrm{CFU} \mathrm{g}^{-1}\right)$, while total mesophilic bacteria were $4.19 \log \mathrm{CFU} \mathrm{g}{ }^{-1}$ and total coliforms were $2.34 \log \mathrm{CFU} \mathrm{g}{ }^{-1}$. All considered microbiological indices increased constantly over the whole storage period, especially during 
the first 7 days of storage (data not shown). Also, these parameters were influenced by the packaging system; in particular, at 9 days total mesophilic bacteria, yeasts, and moulds, were present at significantly lower concentrations in lettuces packed under $\mathrm{Ar} / \mathrm{CO}_{2}$ with the XCTGV film than in other, differently packed samples (Table 2).

Table 2. Effect of packaging system on microbiological quality parameters of fresh-cut iceberg lettuce

\begin{tabular}{|c|c|c|c|c|c|}
\hline \multirow{2}{*}{$\begin{array}{l}\text { Cell load } \\
\left(\log \text { CFU g }{ }^{-1}\right)\end{array}$} & \multicolumn{4}{|c|}{ Packaging system } & \multirow[b]{2}{*}{$F$} \\
\hline & $\begin{array}{l}\mathrm{XCTGV} \\
\mathrm{Ar} / \mathrm{CO}_{2}\end{array}$ & $\begin{array}{l}\mathrm{XCTGV} \\
\mathrm{N}_{2} / \mathrm{CO}_{2}\end{array}$ & $\mathrm{CTG} \mathrm{Ar} / \mathrm{CO}_{2}$ & $\mathrm{CTG} \mathrm{N}_{2} / \mathrm{CO}_{2}$ & \\
\hline Total mesophilic bacteria & $4.88 \mathrm{a}$ & $5.46 \mathrm{~b}$ & $5.32 b$ & $5.95 \mathrm{c}$ & $9.71 * * *$ \\
\hline Yeasts & $0.90 \mathrm{a}$ & $1.54 \mathrm{ab}$ & $2.38 \mathrm{~b}$ & $2.66 \mathrm{~b}$ & $3.60 *$ \\
\hline Moulds & $0.80 \mathrm{a}$ & $1.22 \mathrm{ab}$ & $2.08 \mathrm{~b}$ & $1.93 \mathrm{~b}$ & $3.29 *$ \\
\hline Total coliforms & $3.65 \mathrm{a}$ & $3.51 \mathrm{a}$ & $3.83 a$ & $3.51 \mathrm{a}$ & NS \\
\hline Pseudomonas spp. & $0.96 \mathrm{a}$ & $0.96 \mathrm{a}$ & $0.85 \mathrm{a}$ & $0.95 \mathrm{a}$ & NS \\
\hline
\end{tabular}

XCTGV: film with anti-UV compounds; CTG: film without anti-UV compounds.

Data in the same row with different letters are significantly different (LSD test at $\mathrm{P}<0.05$ ); NS: not significant; *significant for $\mathrm{P}<0.05$; ***significant for $\mathrm{P}<0.001$; F: calculated Fisher's $\mathrm{F}$.

Either the type of film or the type of gas mixture exerted a positive effect, especially on the total mesophilic bacteria count. The number of these microorganisms found in the samples packed under CTG film was about 0.5 logarithmic units higher than corresponding samples packed under XCTGV, and this increase in the microbial count could be ascribed to the light, considering the greater sweating that took place in the samples packed with the film manufactured without anti-UV additives and which stimulates microbial growth (OLARTE et al., 2009). Moreover, the lower level of mesophilic bacteria assessed in the lettuce samples packed under the gas mixture containing Ar could confirm the role of this noble gas in affecting microbial growth, beside improving overall quality of fresh-cut vegetables (RocculI et al., 2004, 2005; ZHANG et al., 2008). Even if there was a difference in the microflora among the different packed lettuces, the total aerobics and total coliforms counts on fresh-cut lettuce were within the range reported by SORIANO and co-workers (2000).

\section{Conclusions}

The use of a packaging film with anti-UV properties in combination with PAP enriched with $\operatorname{Ar}\left(\mathrm{Ar} / \mathrm{CO}_{2} 80 / 20 \%\right)$ showed to be a promising mean to better preserve lettuce from deterioration processes of chemical, enzymatic, and microbial origin, hence improving the shelf-life of the product. The anti-UV film exerted a positive influence also when a $\mathrm{N}_{2} / \mathrm{CO}_{2}$ $(70 / 30 \%)$ atmosphere was utilized, even if browning phenomena and vitamin $\mathrm{C}$ losses were more intense. The use of a non-anti-UV film resulted always in a quicker and severe deterioration of lettuce quality characteristics, with a vitamin $\mathrm{C}$ reduction of more than $70 \%$ and an increase of browning intensity of over $50 \%$ after 7 days of storage when associated with a $\mathrm{N}_{2} / \mathrm{CO}_{2}(70 / 30 \%)$ packaging atmosphere. Also, the colour retention was affected by the packaging system, and also in this case the best results were obtained by packaging the lettuce with the anti-UV film under an atmosphere enriched in Ar. 
These results suggest a positive role both for Ar and the anti-UV film in improving the shelf-life of lettuce. However, taking into account the current industrial production costs for fresh-cut lettuce, and above all the street price for the consumers, a compromise between costs and product quality should be attained. In this case, packaging of lettuce under a $\mathrm{N}_{2} /$ $\mathrm{CO}_{2}(70 / 30 \%)$ atmosphere associated with the use of an anti-UV film may represent a reasonable solution in order to avoid the cost associated with the use of Ar, but at the same time to preserve the lettuce quality characteristics.

The authors would like to thank Assunta Romaniello for her skilful technical assistance. The authors would like to thank Società Agricola srl "Ortomad" and VIBAC SpA for supplying the lettuce samples and the packaging films.

\section{References}

Ayala, F., Echávarri, J.F., Olarte, C. \& Sanz, S. (2009): Quality characteristics of minimally processed leek processed using different films and stored in lighting conditions. Int. J. Food Sci. Tech., 44, 1333-1343.

AOAC (1990): Official methods of analysis of AOAC: food composition; additives; natural contaminants. HeLrich, K. (Ed.), vol II. AOAC, Arlington. Titratable acidity: method no. 942.15; Brix: no. 932.12.

Couture, R., Cantwell, M.I., Ke, D. \& Saltveit, M.E. (1993): Physiological attributes related to quality attributes and storage life of minimally processed lettuce. Hortic. Sci., 28, 723-725.

Galgano, F., Favati, F., Lapelosa, L., Albanese, D. \& Montanari, L. (2002): Effect of chilling on the vitamin C content of fennel during storage. Ital. J. Food Sci., 14, 167-173.

Galgano, F., Condelli, N., Favati, F., Di Bianco, V., Perretti, G. \& Caruso, M.C. (2015): Biodegradable packaging and edible coating for fresh-cut fruits and vegetables. Ital. J. Food Sci., 27, 1-20.

INSKEEP, W.P. \& BLOOM, P.R. (1985): Extinction coefficients of chlorophyll a and b in N,N-dimethylformamide and $80 \%$ acetone. Plant Physiol., 77, 483-485.

Jamie, P. \& Saltveit, M.E. (2002): Postharvest changes in broccoli and lettuce during storage in argon, helium and nitrogen atmospheres containing 2\% oxygen. Postharvest Biol. Tech., 26, 113-116.

Martínez-Sánchez, A., Tudela, J.A., Luna, C., Allende, A. \& Gil, M.I. (2011): Low oxygen levels and light exposure affect quality of fresh-cut Romaine lettuce. Postharvest Biol. Tech., 59, 34-42.

Olarte, C., Sanz, S., Echavarri, J.F. \& Ayala, F. (2009): Effect of plastic permeability and exposure to light during storage on the quality of minimally processed broccoli and cauliflower. Food Sci. Technol., 42, 402-411.

O’Beirne, D., Murphy, E. \& Ni Eidhin, D. (2011): Effects of argon enriched low-oxygen atmospheres and of highoxygen atmospheres on the kinetics of polyphenoloxidases (PPO). J. Food Sci., 76, E73-E77.

Rico, D., Martín-Diana, A.B., Barat, T.J.M. \& Barry-Ryan, C. (2007): Extending and measuring the quality of fresh-cut fruit and vegetables: a review. Trends Food Sci. Tech., 18, 373-386.

Rocculi, P., Romani, S. \& Dalla Rosa, M. (2004): Evaluation of physico-chemical-parameters of minimally processed apples packed in non-conventional modified atmosphere. Food Res. Int., 37, 329-335.

Rocculi, P., Romani, S. \& Dalla Rosa, M. (2005): Effect of MAP with argon and nitrous oxide on quality maintenance if minimally processed kiwifruit. Postharvest Biol. Tech., 35, 319-328.

Rojas-Graü, M.A., Oms-Oliu, G., Soliva-Fortuny, R. \& Martín-Belloso, O. (2009): The use of packaging techniques to maintain freshness in fresh-cut fruits and vegetables: a review. Int. J. Food Sci. Tech., 44, 875889.

Sanz, S., Olarte, C., Echávarri, J.F. \& Ayala, F. (2007): Influence of exposure to light on the sensorial quality of minimally processed cauliflower. J. Food Sci., 72, S12-S18.

Sanz, S., Olarte, C., Ayala, F. \& Echávarri, J.F. (2009): Evolution of quality characteristics of minimally processed asparagus during storage in different lighting conditions. J. Food Sci., 74, S296-S302.

Soriano, K.V., Rico, M.H., Moltó, J.C. \& Mañes, J. (2000): Assessment of the microbiological quality and wash treatments of lettuce served in university restaurants. Int. J. Food Microbiol., 58, 123-128.

SPENCER, K.C. \& Humphreys, D.J. (2003): Argon packaging and processing preserves and enhances flavor, freshness and shelf life of foods. -in: Cadwallader, K.R. \& Weenen, H. (Eds) Freshness and shelf-life of foods. American Chemical Society, Washinghton. pp. 270-291.

Zhang, M., Zhan, Z.G., Wang, S.J. \& TANG, J.M. (2008): Extending the shelf-life of asparagus spears with e compressed mix of argon and xenon gases. LWT-Food Sci. Technol., 41, 686-691. 